\title{
PERSPEKTIF GEOGRAFI DALAM MEMAHAMI KONTEKS PERUBAHAN IKLIM
}

\author{
Andri Noor Ardiansyah \\ Universitas Islam Negeri (UIN) Syarif Hidayatullah Jakarta \\ Email: noorandri@gmail.com
}

Naskah diterima : 23 Maret 2015, direvisi : 25 April 2015, disetujui : 25 Mei 2015

\begin{abstract}
Climate change is happening today is a necessity that we should not ignore. No other indicator is the increasing temperature of the Earth from 1860 until today, and rising sea levels. The main trigger is the increasing concentration of green house effect (GHE) emissions, particularly carbon dioxide (CO2) in the atmosphere. This is caused by the increasing buman activity as well, such as industrial activities, the use of motor vehicles, and rampant illegal logging. If left unchecked it will have an impact in the form of threats to human life in all areas. Therefore we need a comprehensive knowledge in studying the phenomenon of climate change systematically. Such knowledge is nothing else can be obtained through a given geography learning in educational institutions. Geography provides a way to analyze the phenomenon by using three approaches, namely; approach to spatial, ecological, and complex region.
\end{abstract}

Keywords: Climate change; geography analysis

\begin{abstract}
Abstrak
Perubahan iklim yang terjadi dewasa ini merupakan suatu keniscayaan yang tidak bisa terhindarkan. Indikatornya tiada lain ialah semakin meningkatnya suhu bumi dari tahun 1860 hingga saat ini dan kenaikan permukaan air laut. Pemicu utamanya ialah semakin meningkatnya konsentrasi gas rumah kaca (GRK), terutama gas karbondioksida (CO2) yang terdapat di atmosfer. Hal ini sebagai akibat dari semakin meningkatnya aktivitas manusia, seperti kegiatan industri, penggunaan kendaraan bermotor, dan maraknya penebangan hutan secara liar. Apabila hal ini terus dibiarkan akan berdampak pada timbulnya ancaman terhadap kehidupan manusia di segala bidang. Oleh karenanya, diperlukan suatu pengetahuan yang komprehensif dalam mengkaji fenomena perubahan iklim secara sistematis. Pengetahuan tersebut tiada lain dapat diperoleh melalui pembelajaran geografi yang diberikan di institusi pendidikan. Geografi memberikan cara menganalisis fenomena dengan menggunakan tiga pendekatan, yakni pendekatan spasial, ekologi, dan kompleks wilayah.
\end{abstract}

Kata kunci: perubahan iklim; analisis geografi

Pengutipan: Ardiansyah, A., N. (2015). Perspektif Geografi dalam Memahami Konteks Perubahan Iklim. SOSIO DIDAKTIKA: Social Science Education Journal, 2(1), 2015, 1-13. 67-75. doi:10.15408/ sd.v2i1.1351

Permalink/DOI: http://dx.doi.org/10.15408/sd.v2i1.1351 


\section{A. Pendahuluan}

Saat ini dunia sedang digoncang isu perubahan iklim karena dampaknya yang luas terhadap kehidupan dan mengancam kehidupan manusia. Perubahan iklim terjadi sebagai implikasi adanya pemanasan global, yang disebabkan oleh kenaikan Gas Rumah Kaca (GRK), terutama karbondioksida $\left(\mathrm{CO}_{2}\right)$ dan metana $(\mathrm{CH})$. Suhu bumi hingga saat ini masih terus meningkat. Peningkatan suhu bumi yang tak terkendali akan menyebabkan peningkatan pemanasan global, yang akan menyebabkan pula kenaikan permukaan air laut, pergeseran musim, meningkatnya curah hujan di musim penghujan dan kering berkepanjangan di musim kemarau. Salah satu pemicu terjadinya peningkatan GRK yang menyebabkan peningkatan suhu bumi adalah kegiatan manusia.

Perubahan iklim terjadi secara perlahan dalam jangka waktu yang cukup panjang, yakni antara 50-100 tahun. Berikut data-data yang dihimpun oleh Intergovermental Panel on Climate Change (IPCC) yang menggambarkan kondisi perubahan iklim yang terjadi saat ini adalah:

1. Telah terjadi kenaikan suhu rata-rata sebesar antara periode 1860-2000.

2. 11 dari 12 tahun terakhir (1995-2006) merupakan tahun-tahun dengan rata-rata suhu terpanas sejak dilakukan pengukuran suhu pertama kali pada tahun 1850 .

3. Telah terjadi kenaikan permukaan air laut global rata-rata sebesar $1,8 \mathrm{~mm} /$ tahun antara periode 1961-2003.

4. Telah terjadi kekeringan yang lebih intensif pada wilayah yang lebih luas sejak tahun 1970an, terutama di daerah tropis dan sub tropis. ${ }^{1}$

Berawal dari permasalahan perubahan iklim yang sedang melanda dunia, maka diperlukan suatu pengetahuan kepada masyarakat luas, agar masyarakat mengetahui dan bijak dalam memahami serta menyikapi segala bentuk yang menyangkut tentang perubahan iklim dan dampaknya. Pengetahuan yang relevan kaitannya terhadap konteks perubahan iklim dan dampaknya ialah tiada lain dengan melalui ilmu Geografi baik yang diberikan melalui pembelajaran di sekolah ataupun di Perguruan

\footnotetext{
1 IPCC, A report of the Working Group of the Intergovernmental Panel on Climate Change Summary for Policymakers. Geneva,2007
}

Tinggi (bagi yang mengambil jurusan geografi). Ilmu Geografi memberikan pengetahuan yang mendasar terhadap gejala alam dan sosial yang terjadi di permukaan bumi, termasuk perubahan iklim di dalamnya.

\section{B. Esensi Ruang Lingkup Geografi}

Geografi baik sebagai ilmu murni maupun ilmu terapan, turut serta memberikan sumbangsih pengetahun kepada peserta didik pada semua jenjang pendidikan (SD, SMP, SMA, dan Perguruan Tinggi). Hal ini agar peserta didik memilki kemampuan untuk berpikir kritis, analitis, dan sistematis terhadap segala gejala alam dan sosial yang terjadi, termasuk perihal perubahan iklim. Berbagai riset geografi yang berkenaan dengan perubahan iklim dan bagaimana untuk mengurangi dampak telah banyak diteliti oleh para ahli dan dijadikan sebagai bahan pengayaan pembelajaran geografi.

Banyak definisi geografi yang dikemukakan oleh berbagai ahli baik dari luar ataupun dalam negeri, seperti ; (a) De Jong "geografi yaitu ilmu yang berbeda-beda hubungan dalam ruang (chorologi), melalui pengelompokan gejala sebagai scopeatau objekgeografiyaitu gejala di permukaan bumi yang berbeda-beda (areal differentiation)", (b) Elsworth Huntington " geografi adalah studi tentang alam dan persebarannya, melalui relasi antara lingkungan dengan aktivitas atau kualitas manusia, (c) Strabo " geografi erat kaitannya dengan karakteristik tertentu mengenai suatu tempat dengan memperhatikan juga hubungan antara berbagai tempat secara keseluruhan, dan (d) Bintarto " geografi mempelajari hubungan kausal gejala-gejala di permukaan bumi dan peristiwa-peristiwa yang terjadi di permukaan bumi, baik secara fisik maupun yang menyangkut makhluk hidup beserta permasalahannya melalui pendekatan, ekologi, dan regional untuk kepentingan program, proses, dan keberhasilan pembangunan. $^{2}$

Merujuk pada apa yang dikemukakan oleh Ikatan Geografi Indonesia (IGI) hasil kesepakatan seminar dan lokakarya di Semarang tahun 1988, bahwa geografi adalah ilmu yang mempelajaripersamaandanperbedaanfenomena

2 Gurniwan Kamil Pasya, Geografi, Pemabaman Konsep dan Metodologi, (Bandung: Buana Nusantara, 2002), h. 79-82 
geosfer yang ditinjau dari sudut pandang kelingkunganan dan kewilayahan dalam konteks keruangan. ${ }^{3}$ Dari pengertian tersebut jelaslah bahwa ilmu geografi konsen terhadap kajian geosfer, yaitu lapisan bumi, yang di dalamnya berupa; atmosfer, lithosfer, pedosfer, hidrosfer, biosfer, dan antroposfer. Kesemuanya disebut sebagai objek material geografi. Berbagai objek material yang terhimpun dalam geosfer itu akan dianalisis dengan sudut pandang keruangan, kelingkunganan dan kewilayahan. Ketiga sudut pandang atau analisis terhadap objek material dinamakan pula sebagai objek formal geografi. Objek formal tersebut yang membedakan tiaptiap disiplin ilmu walaupun terdapat kesamaan objek matrerialnya.

Dalam ketegasan analisisnya/cara pandang terhadap objek material, geografi dilengkapi pula dengan menggunakan berbagai prinsip. Menurut Widoyo prinsip geografi adalah pokok-pokok pikiran yang mendasari pola kajian studi geografi. Adapun berbagai prinsip tersebut antara lain: prinsip sebaran/distribusi, interelasi/hubungan, diskripsi/diskripsi, dan korologi/wilayah. ${ }^{4}$ Prinsip sebaran akan mempertanyakan keberadaan gejala/fenomena yang tersebar secara tidak merata di permukaan bumi. Prinsip interelasi akan melihat hubungan yang saling keterkaitan atau ketergantungan antar fenomena. Prinsip diskripsi menitikberatkan kepada kajian geografi harus dilengkapi dengan peta, tabel dan analisis data statistik. Prinsip korologi adalah ruang, yang memiliki arti bahwa segala gejala fakta dan masalah ditinjau dari penyebarannya dan interelasinya tidak terlepas dari eksistensi ruang itu sendiri. Oleh karenanya prinsip keempat ini dapat dikatakan sebagai prinsip gabungan dari ketiga prinsip sebelumnya.

Dilihat dari objek materialnya, secara jelas substansi ilmu geografi menyentuh aspek atmosfer, yang secara material mengkaji tentang gejala iklim dan dinamikanya serta pengaruhnya terhadap kehidupan mahkluk hidup di dalamnya. Fenomena perubahan iklim adalah salah topik yang dikaji dalam atmosfer dan menjadi perbincangan hangat saat ini, hanya saja tingkat kedalaman kajian per jenjang

Widoyo Alfandi, Epistemologi Geografi, (Yogyakart : Gadjah Mada University Press, 2001), h.86
}

pendidikan berbeda-beda. Dalam pengkajian atmosfer terhadap perubahan iklim akan dibahas secara komprehensif baik mengenai faktor-faktor yang mempengaruhinya, dampak yang ditimbulkannya, dan tentunya bagaimana upaya untuk mengurangi ancaman atau bahaya yang ditimbulkannya.

Perubahan iklim dapat dilihat dari sudut pandang/perspektif atau objek formal geografi, yaitu keruangan, kelingkunganan dan kewilayahan. Masing-masing pendekatan tersebut memiliki cara analisis yang berbeda terhadap perubahan iklim. Oleh karenanya melalui ilmu geografi yang diberikan di dunia pendidikan baik secara aspek pengetahuan (knowledge) ataupun ilmu (science) akan menambah wawasan yang integratif dalam memahami suatu gejala perubahan iklim.

\section{Analisis Geografi Terhadap Perubahan Iklim}

Setiap bidang disiplin ilmu memiliki analisis yang berbeda-beda terhadap objek materialnya. Walaupun ada kesamaan objek meterialnya, namun memiliki kekhasan dari objek formalnya. Hal ini agar lebih jelas dalam memahami maksud dari substansi ilmu tersebut dan pembeda dari disiplin ilmu yang lain. Ada tiga analisis yang menjadi ciri khas geografi, yakni analisis spasial, analisis ekologi, dan analisis kompleks wilayah. Kaitannya dengan perubahan iklim, maka tentunya geografi menggunakan ketiga analisis tersebut.

\section{Analisis spasial}

Menurut Blaut, secara absolut, spasial/ space atau ruang dapat diartikan wadah yang bersifat khas, fisik dan empiris, yang ditentukan berdasarkan ukuran geometri, berdimensi tiga, yaitu panjang, lebar, dan tinggi. Lebih lanjut, Blaut menyebutkan ruang relatif adalah ruang di atas mana berlangsung suatu relasi kegiatan yang terikat pada proses dan waktu. ${ }^{5}$ Dari definisi ruang di atas, maka menurut Gurniwan Kamil Pasya, secara subtansial analisa spasial atau keruangan dalam geografi menekankan kepada aspek spatial pattern, spatial system, dan $\frac{\text { spatial process. }^{6}}{5 \quad \text { Ibid.. h. } 70}$

6 Kamil, Gurniwan Pasya, Geografi, Pemahaman Konsep dan Metodologi, 


\section{a. Spatial Pattern}

Spatial pattern atau pola spasial menekankan bahwa gejala alam dan sosial dalam ruang memiliki sifat keteraturan. Keteraturan gejala alam dan sosial berbeda satu sama lainnya, yang tercermin adanya pembagian sebaran (distribusi) berbagai gejala dalam ruang yang dimanifestasikan dengan menggunakan peta. Kaitannya dengan perubahan iklim, maka tinjauan spatialpattern akan mengarahkan kepada pola distribusi indikator terjadinya perubahan iklim dan dampak perubahan iklim itu sendiri di berbagai belahan dunia.

Terjadinya dampak perubahan iklim secara global setidaknya dipicu oleh naiknya suhu permukaan. Akibat yang mungkin terjadi jika suhu permukaan meningkat $1{ }^{\circ} \mathrm{C}$ akan berdampak kepada masalah yang menimpa dunia, seperti yang dimodelkan dalam peta di bawah ini.

Gambar 1. Peta Model Dampak Akibat

Kenaikan Suhu Permukaan $1^{\circ} \mathrm{C}$ di Belahan

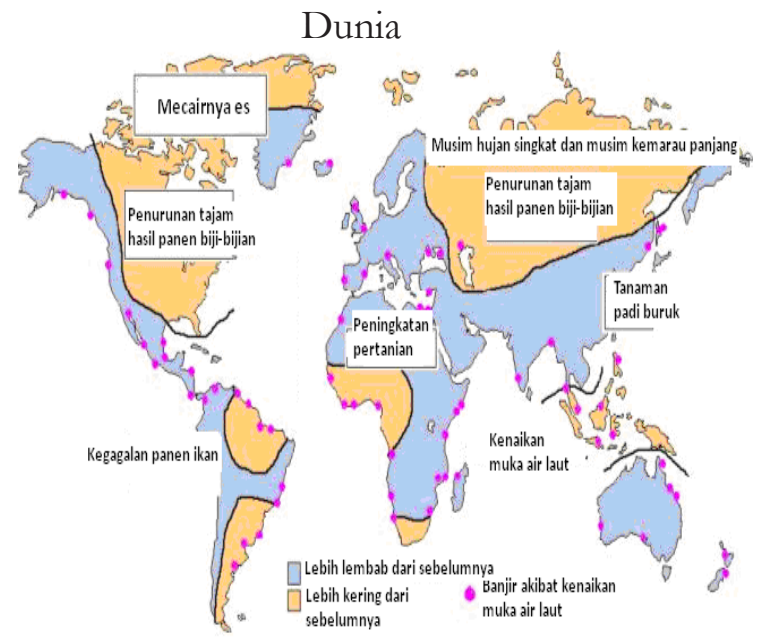

Sumber: Harwood Academic publishers and A word Map of descritification UNESCO/FAO, 1983

Dari peta di atas, nampak bahwa kenaikan suhu $1^{\circ} \mathrm{C}$ akan berakibat kepada kenaikan muka air laut yang melanda berbagai benua. Hal ini berdampak pula banjir di sekitar pesisir, kegagalan panen ikan di pantai barat Amerika Selatan, mencairnya es di Kutub Utara, penurunan drastis hasil panen biji-bijian di Amerika Serikat dan Asia bagian utara, dan terjadinya musim hujan yang lebat dalam waktu

(Bandung: Buana Nusantara, 2002), h.93 singkat sedangkan musim kemarau dalam waktu yang sangat panjang.

Selain gambar peta di atas, dalam konteks spatial pattern bisa kita lihat dari pemodelan yang dikembangkan oleh Harwood Acasemic publishers and $A$ word Map of descritification UNESCO/FAO. Dalam model peta yang dibuatnya terdapat gejala perluasan gurun akibat perubahan iklim, seperti yang tergambar dalam peta di bawah ini.

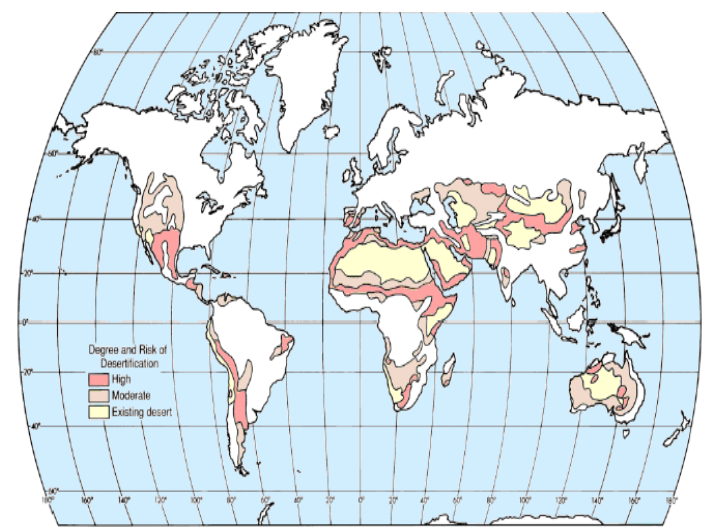

Sumber: Harwood Academic publishers and $A$ word Map of descritification UNESCO/FAO, 1983

Dari peta di atas, terlihat bahwa gejala perluasan gurun akibat perubahan iklim akan nampak pada kisaran lintang 0-60 $\mathrm{LU} / \mathrm{L}$, yakni benua Afrika, Asia Barat, Australia, dan Pantai Barat Amerika utara hingga selatan berpotensi terjadinya perluasan wilayah gurun.

\section{b. Spatial System}

Spatial system atau keterkaitan ruang menekankan kepada aspek di mana terdapat hubungan saling keterkaitan antara elemenelemen ruang. Perubahan iklim yang terjadi tidak hanya berkisar seputar fenomena pada lapisan atmosfer saja, melainkan memiliki keterkaitan dampak terhadap aspek lainnya seperti hidrosfera (lapisan air), oseanosfer (lapisan laut), biosfer (lapisan mahkluk hidup), dan lapisan antroposfer (lapisan manusia). Berikut beberapa kajian dampak perubahan iklim yang terkait analisis spatial system dalam geografi sebagai berikut.

1) Dampak perubahan iklim terhadap kenaikan muka air laut

Meningkatnya suhu bumi bisa menyebabkan mencairnya es di daerah kutub. Menurut IPCC (Intergovernmental Panel on Climate Change), dalam 100 tahun terakhir telah terjadi peningkatan 
air laut setinggi $10-25 \mathrm{~cm}$. Sementara menurut laporan Greenpeace, diperkirakan pada tahun 2100 mendatang akan terjadi peningkatan air laut setinggi 19-95 cm. Peningkatan air laut setinggi 1 meter akan mengakibatkan hilangnya pulau atau daratan di dunia.

a) Hilangnya daratan Mesir 1\%, Belanda $6 \%$, Bangladesh $17,5 \%$ dan $80 \%$ atol di kepulauan Marshall.

b) Tenggelamnya pulau-pulau di Fiji, Samoa, Vanutu, Jepang, Filipina, serta Indonesia. Hal ini berarti puluhan juta orang yang hidup di pesisir pantai harus mengungsi ke daerah yang lebih tinggi. ${ }^{7}$

Naiknya permukaan air laut akan mengakibatkan kurangnya daya tahan pesisir pantai sehingga rentan tehadap erosi. Hal ini juga mengakibatkan rusaknya berbagai infrastruktur dan pemukiman di tepi pantai. Fenomena ini bisa menimbulkan pengungsian

Naiknya permukaan air laut akan mengancam kehidupan ekosistem pesisir di wilayah pesisir. Seperti yang terjadi di wilayah pesisir Jawa, Aceh, Kalimantan, Sulawesi telah terjadi hancurnya tambak-ikan dan udang (UNDP, 2007), kejadian ini praktis para nelayan akan mengalami kerugian. Para ahli meramalkan akibat pemanasan global pada tahun 2050 akan mengalami degradasi terumbu karang sebanyak $98 \%$ dan biota laut $50 \%$.

2) Dampak perubahan iklim terhadap sumber daya air

Pada pertengahan abad ini, rata-rata aliran air sungai dan ketersediaan air bersih di daerah sub polar serta daerah tropis basah diperkirakan akan meningkat sebanyak 10-40\%. Sementara di daerah subtropis dan daerah tropis yang kering, air akan berkurang 10-30\% sehingga daerah-daerah yang sekarang sering mengalami kekeringan akan semakin parah kondisinya.

3) Dampak perubahan iklim terhadap ekosistem

Kemungkinan punahnya $20-30 \%$ spesies tanaman dan hewan bila terjadi kenaikan suhu rata-rata global sebesar $1,5-2,5{ }^{\circ} \mathrm{C}$. Meningkatnya tingkat keasaman laut karena bertambahnya karbondioksida di atmosfer

\footnotetext{
7 IPCC. A report of the Working Group of the Intergovernmental Panel on Climate Change Summary for Policymakers. Geneva, 2007.
}

diperkirakan akan membawa dampak negatif pada organisme-organisme laut seperti terumbu karang serta spesies-spesies yang hidupnya begantung kepada organisme tersebut.

4) Dampak Perubahan Iklim Terhadap Pemukiman Perkotaan

Kenaikan muka air laut antara 8 hingga 30 cm juga akan berdampak negatif pada kotakota pesisir seperti Jakarta dan Surabaya yang akan makin rentan terhadap banjir dan limpasan badai. Masalah ini sudah menjadi makin parah di Jakarta karena bersamaan dengan kenaikan muka air laut, permukaan tanah turun.

\section{5) Dampak Perubahan Iklim Terhadap Pertanian}

Produktivitas pertanian di daerah tropis akan mengalami penurunan bila terjadi kenaikan suhu rata-rata global antara $1-2{ }^{\circ} \mathrm{C}$, sehingga mengakibatkan risiko bencana kelaparan. Meningkatnya frekuensi kekeringan dan banjir diperkirakan akan memberikan dampak negatif pada produktifitas lokal, terutama pada sektor penyediaan pangan di daerah subtropis dan tropis. Terjadinya perubahan musim di mana musim kemarau menjadi lebih panjang sehingga menyebabkan gagal panen

\section{c. Spatial Process}

Spatial process merupakan analisis geografi terhadap perubahan dalam ruang. Ruang senantiasa mengalami perubahan dari dimensi waktu yang satu ke dimensi waktu yang lainnya, baik yang disebabkan oleh faktor fisik ataupun intervensi faktor manusia di dalamnya. Perubahan dalam ruang tercermin dengan semakin panasnya rata-rata suhu bumi dari waktu ke waktu, seperti yang tergambar dalam grafik 1.

\section{Grafik 1. Rata-Rata Temperatur Global}

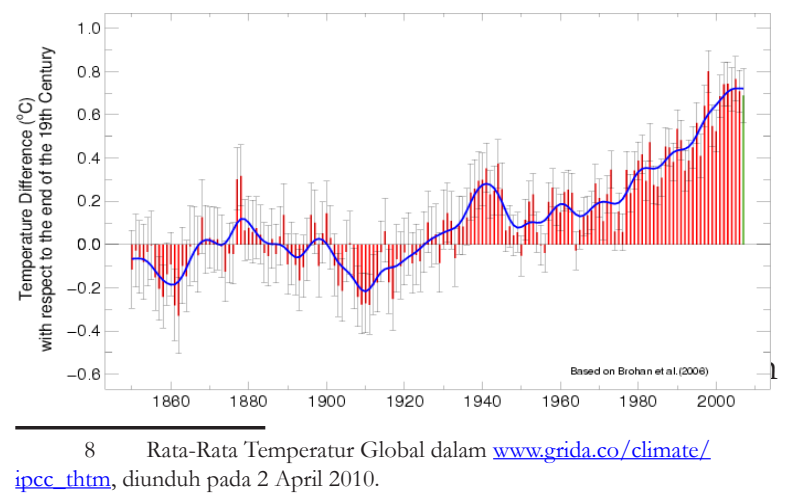


terjadi trend peningkatan suhu global dari tahun 1860 hingga 2000 atau sekitar 140 tahun lamanya. Pada tahun 2000 ke atas model mengisyaratkan akan terus mengalami kenaikan suhu. Hal ini dipicu oleh semakin meningkatnya pula konsentrasi $\mathrm{CO}_{2}$, seperti yang terlihat pada grafik 2 di bawah ini.

Grafik 2. Hubungan Antara Konsentrasi $\mathrm{CO}_{2}$ dan Kenaikan Suhu

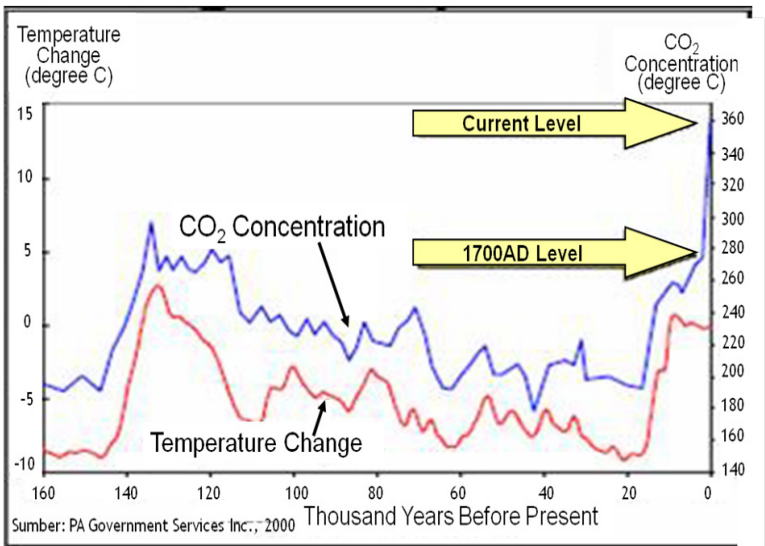

A word Map of descritification UNESCO/FAO, 1983

Karbondioksida adalah salah satu GRK yang merupakan hasil pembakaran bahan bakar fosil yang tidak sempurna yang apabila naik ke atmosfer akan mempunyai waktu tinggal sekitar 4 sampai 6 tahun. Bayong menyebutkan bahwa kosentrasi $\mathrm{CO}_{2}$ di udara telah naik dari 295 ppm (parts per million) $=0,03 \%$, sebelum zaman industri, sekarang menjadi $331 \mathrm{ppm} .{ }^{9}$ Menjelang tahun 2000, beberapa ilmuwan memperkirakan kenaikan $\mathrm{CO}_{2}$ berkisar antara 375 dan 400 ppm yang dapat menyebabkan kenaikan suhu bumi sekitar $0,5^{\circ} \mathrm{C}$. Peningkatan konsentrasi GRK di atmosfer menyebabkan perubahan suhu bumi. Suhu global dilaporkan telah meningkat antara $0,3^{\circ} \mathrm{C}-0,6^{\circ} \mathrm{C}$ bila dibandingkan dengan suhu bumi pada tahun 1860. Suhu Bumi pada tahun sebelum 1860 relatif stabil.

Kenaikan suhu bumi tersebut berkontribusi dengan semakin tingginya lapisan es mencair yang berdampak terhadap kenaikan muka air laut, sehingga menyebabkan terendamnya sebagian daratan, yang berarti terjadi perubahan luas daratan di permukaan bumi. Menurut IPCC (Intergovermental Panel on Climate Change) saat ini terdapat bukti yang menunjukan bahwa $\begin{array}{cc}9 & \text { Bayong, T.H.K.dkk, Klimatologi Umum, (Bandung: ITB Bandung, } \\ \text { 1995). h.267 } & \end{array}$ lapisan es di Antartika dan Greenland perlahan berkurang dan berkontribusi terhadap kenaikan air laut. Pencairan es kutub telah mengakibatkan muka air laut naik mencapai 4-6 meter. ${ }^{10}$

\section{Analisis Ekologi}

Analisis yang kedua dalam ilmu geografi ialah melihat hubungan antara manusia dengan lingkungannya. Analisis geografi pada pendekatan ekologi menekankan pada interaksi dan interdepedensi antara manusia dengan lingkungan hidupnya. Lingkungan geografi sama pengertiannya dengan lingkungan hidup. Interaksi dan interdepedensi adalah fungsifungsi dalam sistem, yang disebut sebagai ekogeografi. Eko-geografi bersifat antroposentris, di mana lingkungan alam sudah dimasukkan di dalam kehidupan budidaya manusia dan sebaliknya manusia merupakan bagian dari lingkungan hidup. Hubungan manusia dengan lingkungannya merupakan hubungan dua arah.

Terkait terhadap perubahan iklim, tentunya melalui analisis ini fenomena tersebut akan dikaitkan dengan aktivitas manusia di dalamnya. Tentunya kita sepakat bahwa peningkatan gas rumah kaca yang merupakan penyebab perubahan iklim disinyalir semakin meningkatnya konsentrasi gas karbondioksida $\left(\mathrm{CO}_{2}\right)$ di atmosfer. Peningkatan GRK disinyalir karena semakin banyaknya industri di belahan dunia yang mengeluarkan $\mathrm{CO}_{2}$.

Berbagai kontribusi GRK terhadap peningkatan suhu bumi, seperti yang terdapat pada grafik di bawah ini.

Grafik 3. Persentase Kontribusi Gas Rumah Kaca

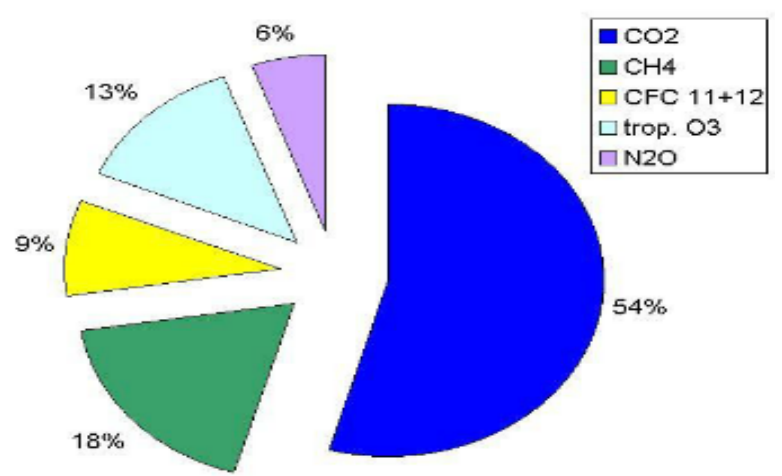

Sumber: wnw.grida.no/climate/ipcc_thtm ${ }^{11}$

\footnotetext{
10 IPCC, A report of the Working Group of the Intergovernmental Panel on Climate Change Summary for Policymakers. Geneva, 2007.

11 Persentase Kontribusi Gas Rumah Kaca dalam www.grida.co/ climate/ipcc thtm, diunduh pada 2 April 2010.
} 
Dari data di atas kontribusi terbesar GRK atau dominan terhadap peningkatan suhu bumi adalah gas $\mathrm{CO}_{2}$ sebesar $54 \%$ dan yang terkecil berasal dari gas CFC sebesasar 9\%. Tinggi gas $\mathrm{CO}_{2}$ tersebut tiada lain karena beragamnya aktifitas manusia, terutama sektor industri, pembangkit tenaga listrik dan transportasi. Seperti yang tersaji dalam ilustrasi pada gambar di bawah ini.

Gambar 3. Perkembangan Konsentrasi $\mathrm{O}_{2}$ di Atmosfer Akibat Aktivitas Manusia

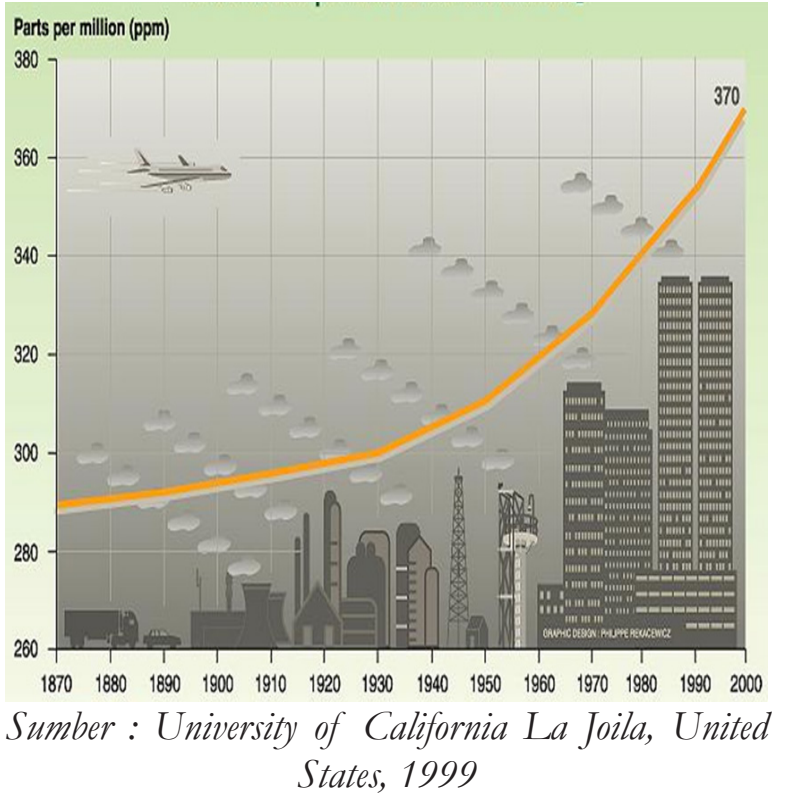

Hasil observasi konsentrasi $\mathrm{CO}_{2}$ di Moana Loa Hawaii sejak tahun 1960 s/d 2005 meningkat sampai $20 \%$. Demikian pula di Indonesia menurut catatan stasiun GAW (Global Atmosferic Watch) Kota Bukit Tinggi Sumatera Barat ternyata juga mengalami konsentrasi $\mathrm{CO}_{2}$, semenjak diadakan pengukuran pada tahun 2004. Pada negara-negara maju seperti Amerika Serkat, Rusia, Jepang, Jerman, Kanada dan Inggris ternyata menjadi pemasok utama $\mathrm{CO}_{2}$ di dunia. Sementara di negara-negara berkembang laju pemakaian kendaraan bermotor kian meningkat jumlahnya, di samping adanya kegiatan penebangan hutan yang dilakukan besar-besaran.

\section{Analisis Kompleks wilayah}

Analisis kompleks wilayah ini lebih menitikberatkan kepada analisis persamaan dan perbedaan wilayah, analisis peramalan wilayah, dan analisis perencanaan wilayah. Ketiga analisis tersebut merupakan analisis yang memiliki hubungan satu sama lainnya, suatu persamaan dan perbedaan wilayah akan memperkirakan/ meramalkan suatu wilayah ke depan dan menentukan bagaimana perencanaan yang terdapat pada wilayah tersebut.

Kaitannya dengan pengkajian perubahan iklim dunia yang di mana salah satu indikator utamanya ialah kenaikan rata-rata suhu global, maka dalam analisis persamaan dan perbedaan wilayah ini akan menampilkan perbedaan respon perubahan suhu di setiap benua. Analisis ini sangat penting untuk melihat seberapa besar kanaikan suhu dari masing-masing benua di dunia. Setelah kita mengetahui perbedaannya tersebut, maka kita akan bertanya yakni mengapa terjadi demikian ? dan tentunya faktor-faktor apa saja yang mempengaruhinya?

Di bawah ini merupakan model yang dikembangkan oleh Summary of Policymakers of the Synthesis Report of the IPCC Fourth Assessment Report (2007) tentang perbedaan perubahan suhu di berbagai benua.

\section{Gambar 4. Peta Perubahan Suhu di Setiap Benua}

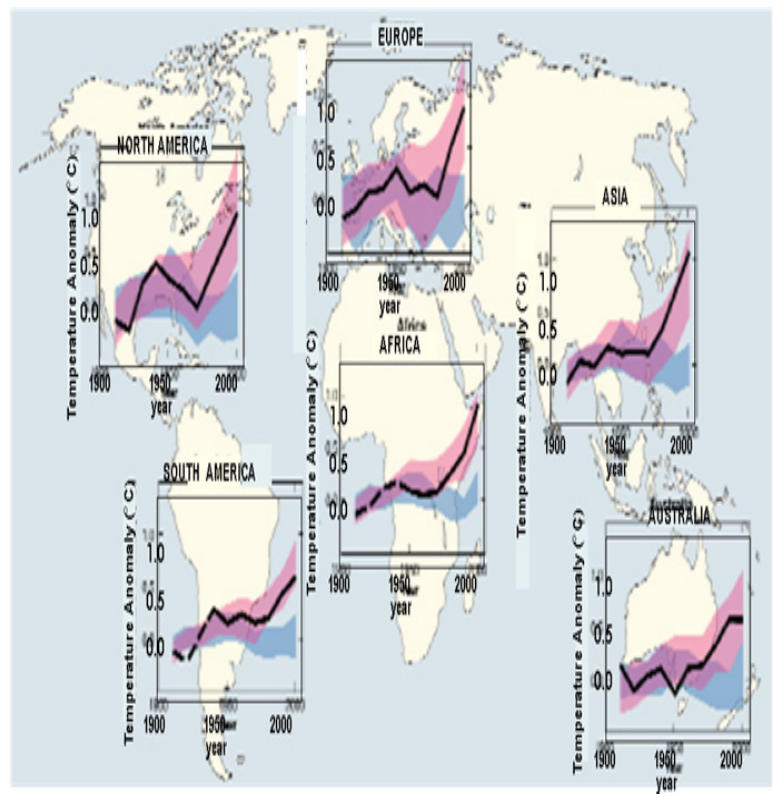

Model hanya memperhitungkan faktor alam (matahari dan debu vulkanik)

Model, memperhitungkan faktor alam dan aktifitas manusia

Sumber: Summary of Policymakers of the Synthesis Report of the IPCC Fourth Assessment Report, Nov 2007 
Dari Peta Perubahan Suhu di Setiap Benua, terlihat suatu komparasi perubahan kenaikan suhu di setiap benua dengan dua model, yakni model pertama yang kenaikan suhu hanya memperhitungkan faktor alam (matahari dan debu vulkanik) dan model kedua memperhitungkan faktor alam dan aktifitas manusia. Model pertama terlihat jelas tidak ada perbedaan yang signifikan bahkan tidak ada perubahan suhu di setiap benua akibat faktor alam (matahari dan debu vulkanik). Model kedua menunjukan terlihat jelas terdapat perbedaan yang nyata perubahan suhu di masing-masing benua akibat bercampurnya faktor alam dan aktifitas manusia, seperti; industri, kendaraan bermotor, kebakaran hutan, dan lain-lain yang menyumbang $\mathrm{CO}_{2}$ ke atmosfer serta berakibat naiknya suhu di berbagai benua.

Dalam kajian persamaan (areal likenesses) dan perbedaan wilayah (areal differentiation) terdapat beberapa persamaan dan perbedaan lonjakan kenaikan suhu di beberapa benua pada model kedua. Kalau kita lihat ada tiga besar benua yang mengalami persamaan lonjakan kenaikan suhu, yaitu benua Eropa menduduki peringkat pertama disusul benua Amerika Utara (USA) di peringkat kedua, dan Benua Asia (khususnya Asia Timur) di peringkat ketiga. Ketiga negara tersebut merupakan wilayah yang di dalamnya banyak kegiatan aktifitas industri yang secara otomatis menghasilkan banyak $\mathrm{CO}_{2}$. Sementara sisanya berupa benua Australia, benua Amerika Selatan, dan benua Afrika tidak mengalami lonjakan kenaikan suhu yang cukup berarti.

Dari analisis persamaan dan perbedaan wilayah tersebut, maka kita bisa meramalkan ke depannya bagaimana kondisi dampak terhadap lingkungan fisik dan manusia di dalamnya dari wilayah yang memiliki pemasok $\mathrm{CO}_{2}$ terbesar ke udara? Dan bagaimana perencanaan wilayah ke depan dalam rangka mengurangi bahaya dampak yang terjadi?

\section{Penutup}

Dampak perubahan iklim kian terus mengancam kehidupan masyarakat dunia. Pengetahuan masyarakat akan adanya perubahan iklim yang terjadi saat ini menjadi suatu keharusan, agar masyarakat memiliki penyikapan serta mengetahui apa yang seharusnya dilakukan dalam mengatasinya. Oleh karenanya diperlukan suatu ilmu dan pengetahuan mendasar yang diberikan melalui jalur pendidikan. Ada beberapa disiplin limu yang diberikan di tingkat sekolah yang berkenaan mengenai tema perubahan iklim, namun tergantung dari sisi penekanan dari objek formal masing-masing disiplin ilmu tersebut. Ilmu geografi memberikan sumbangsih ilmu dan pengetahuan kepada peserta didik secara komprehensif dengan menggunakan objek formal yang menjadi ciri khasnya; yaitu pendekatan atau analisis tersebut, seperti analisis spasial, ekologi, dan kompleks wilayah. Pemahaman integratif akan objek formal geografi beserta aplikasinya, diharapkan mampu menumbuhkan sikap kritis dan analitis dari apa yang terjadi pada lapisan atmosfer dan pengaruhnya pada kehidupan di dalamnya.

\section{E. Daftar Pustaka}

Alfandi, Widoyo. (2001). Epistemologi Geografi. Yogyakarta: UGM Pers.

Bayong, T.H.K.dkk.,(1995). Klimatologi Umum. Bandung: ITB Bandung.

Frank, Louis A.,Sigwarth, J.B. (1986). Atmospheric Holes and Small Comets. Department of Physics and Astronomy, lowa City : University of Lowa

Harwood Academic Publishers and A word Map of Descritification UNESCO/FAO. (1983).

IPCC. (2007). A report of the Working Group of the Intergovernmental Panel on Climate Change Summary for Policymakers. Geneva, Intergovernmental Panel on Climate Change.

Madden, R., P. Julian. (1971). Detection of a 40-50 day oscillation in the ronal wind in the tropical Pacific. J. Atmos. Sci., 28.

Pasya, Kamil, Gurniwan, (2002). Geografi : Pemahaman Konsep dan Metodologi. Bandung : Buana Nusantara.

Sobirin., (2010). Karakteristik Dinamika Cuaca Dan Iklim Di Indonesia, Diktat Kuliah Klimatologi, UI 
Rata-Rata Temperatur Global dalam www.grida. co/climate/ipcc_thtm, diunduh pada 2 April 2010.
Persentase Kontribusi Gas Rumah Kaca dalam www.grida.co/climate/ipcc_thtm, diunduh pada 2 April 2010. 